\title{
APRESENTAÇÃO
}

\author{
Presentation
}

\section{Vaticano II e diálogo com a contemporaneidade}

Q stamos iniciando a publicação da revista Teocomunicação para Vaticano II: o diálogo com o mundo. Passados já mais de cinquenta anos de sua convocação, a abertura ao diálogo com o mundo, como um de seus objetivos e realizado claramente pela Constituição Pastoral Gaudium et Spes, continua necessário e indispensável. A Igreja, provocada por tantos desafios postos pela sociedade dos dias de hoje, já passado o primeiro decênio do século, precisa dialogar com a cultura contemporânea para poder realizar a sua missão evangelizadora.

Tal missão não se restringe ao anúncio da Boa Nova de Jesus Cristo, mas, a partir dela, contribuir para que a pessoa humana seja reconhecida e respeitada em sua dignidade e para que a sociedade possa viver em paz e harmonia, a partir do respeito recíproco e do desejo de caminhar de forma fraterna na busca da solução dos problemas comuns que a afligem. Hoje, a tarefa da Igreja não é apenas anunciar a Deus, mas também favorecer a descoberta do sentido da vida humana. Em uma sociedade que enfraqueceu ou até perdeu o sentido de Deus, se enfraquece e se perde também o sentido da pessoa humana. Eis o grande desafio da pós-modernidade: redescobrir a transcendência. Para os cristãos, este mistério transcendente se aproximou do ser humano por meio da encarnação do Filho de Deus, que, através de sua vida, paixão, morte e ressurreição, revelou ao ser humano a sua maior dignidade e só a partir dele ela se esclarece com toda nitidez (cf. Gaudium et Spes, n. 22).

A presente edição aborda alguns temas do Vaticano II. Inicia com a análise da raiz da formação dos Papas João XXIII e Paulo VI para

\begin{tabular}{|l|l|l|l|l|l|}
\hline Teocomunicação & Porto Alegre & v. 44 & n. 1 & p. 3-4 & jan.-abr. 2014 \\
\hline
\end{tabular}


encontrar aí a dinâmica que levou a Igreja a dialogar com a sociedade contemporânea (Ney de Souza e Edgar da Silva Gomes). Deste brota outro tema importante do último Concílio: a reforma da liturgia de acordo com as orientações emanadas do Vaticano II e a sua continuidade nos dias de hoje (Ângelo Cardita). Outro tema relevante é a questão do pluralismo religioso, que é analisado a partir do Reino de Deus como possível chave hermenêutica para uma cristologia do pluralismo religioso (Adriano Souza Lima).

Temas mais amplos são abordados nos demais artigos. Pedro Calafate discorre sobre consciência crítica da conquista e colonização da América nas Universidades de Coimbra e Évora, no século XVI. Wilmar Luiz Barth estuda a revalorização da religiosidade por parte da psicologia e da medicina na relação com a doença e a cura. Luís Henrique Marques faz uma leitura crítica da obra I fioretti di San Francesco, como um meio de comunicação do cristianismo e, explicitamente, do movimento franciscano. Para finalizar, Geraldo Luiz Borges Hackmann aborda o documento da Comissão Teológica Internacional sobre a Teologia, com o qual são apresentados princípios, perspectivas e critérios para a tarefa teológica.

Pretendemos, a partir deste número, mudar a periodicidade da revista: no lugar da semestralidade, como fizemos a partir do primeiro número de 2011, volume 41, adotaremos o critério da quadrimestralidade. Sendo assim, a partir do presente número, passaremos a ter mais dois números ainda neste ano.

Geraldo Luiz Borges Hackmann Editor 